\title{
Molecular Targets Implicated in the Antiparasitic and Anti-Inflammatory Activity of the Phytochemical Curcumin in Trichomoniasis
}

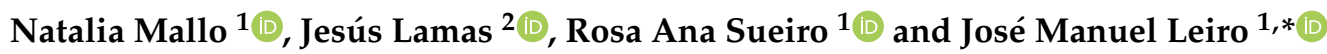 \\ 1 Department of Microbiology and Parasitology, Laboratory of Parasitology, Institute of Research on Chemical \\ and Biological Analysis, Campus Vida, University of Santiago de Compostela, \\ 15782 Santiago de Compostela, Spain; mallo.natalia@gmail.com (N.M.); rosaana.sueiro@usc.es (R.A.S.) \\ 2 Department of Fundamental Biology, Institute of Aquaculture, Campus Vida, \\ University of Santiago de Compostela, 15782 Santiago de Compostela, Spain; jesus.lamas@usc.es \\ * Correspondence: josemanuel.leiro@usc.es; Tel.: +34-881-816031
}

Academic Editor: Chiara Porro

Received: 17 October 2020; Accepted: 12 November 2020; Published: 14 November 2020

\begin{abstract}
Trichomoniasis, is the most prevalent non-viral sexually transmitted disease worldwide. Although metronidazole (MDZ) is the recommended treatment, several strains of the parasite are resistant to MDZ, and new treatments are required. Curcumin (CUR) is a polyphenol with anti-inflammatory, antioxidant and antiparasitic properties. In this study, we evaluated the effects of CUR on two biochemical targets: on proteolytic activity and hydrogenosomal metabolism in Trichomonas vaginalis. We also investigated the role of CUR on pro-inflammatory responses induced in RAW 264.7 phagocytic cells by parasite proteinases on pro-inflammatory mediators such as the nitric oxide (NO), tumor necrosis factor $\alpha(\mathrm{TNF} \alpha)$, interleukin-1beta (IL-1 $\beta)$, chaperone heat shock protein 70 (Hsp70) and glucocorticoid receptor (mGR). CUR inhibited the growth of T. vaginalis trophozoites, with an $\mathrm{IC}_{50}$ value between $117 \pm 7 \mu \mathrm{M}$ and $173 \pm 15 \mu \mathrm{M}$, depending on the culture phase. CUR increased pyruvate:ferredoxin oxidoreductase (PfoD), hydrogenosomal enzyme expression and inhibited the proteolytic activity of parasite proteinases. CUR also inhibited NO production and decreased the expression of pro-inflammatory mediators in macrophages. The findings demonstrate the potential usefulness of CUR as an antiparasitic and anti-inflammatory treatment for trichomoniasis. It could be used to control the disease and mitigate the associated immunopathogenic effects.
\end{abstract}

Keywords: Trichomonas vaginalis; curcumin; hydrogenosomal enzymes; proteinases; proinflammatory cytokines

\section{Introduction}

Trichomonas vaginalis is a flagellated protist that parasitizes the human urogenital tract and causes trichomoniasis. Trichomoniasis is the most prevalent non-viral sexually transmitted disease worldwide and is associated with serious public health problems such as transmission of HIV [1,2]. To infect the urogenital tract, the parasite must develop adaptation systems to support the unfavorable changes that take place in this adverse environment (involving $\mathrm{pH}$, temperature, hormonal changes, menstruation, oscillation in iron concentrations, etc.) [1,3]. Virulence factors such as proteinases contribute to the cytotoxicity of $T$. vaginalis, the immunopathogenic activity and evasion of the immune response during human infection $[2,4,5]$. Cysteine proteinases are some of the most abundant proteinase families in T. vaginalis and in parasites in general $[2,6]$. Several proteinases are reported to be involved in virulence and some are regulated by iron. These proteins have been well studied in T. vaginalis and are known to be implicated in most of the functions necessary for parasitism such as cytoadherence, cytotoxicity, 
hemolysis and immune evasion [1,3,7-11]. Vaginosis, in which T. vaginalis is implicated, it is usually associated with bacterial infections that alter both the normal cervico-vaginal innate immunity and the inflammatory response, producing increased levels of TNF $\alpha$, IL-1 $\beta$, IL-8 and vaginal neutrophils [12].

The protein pyruvate:ferredoxin-oxidoreductase (PfoD) is also regulated by iron in T. vaginalis. This is a key protein in the hydrogenosomal metabolism of the flagellate and is responsible for decarboxylation of pyruvate to acetyl-Co-A, which is thought to be involved in metronidazole resistance [13-16]. Metronidazole is the current treatment for trichomoniasis, and although it is usually effective, the number of metronidazole resistant strains is increasing [2], and new treatments are needed. Natural compounds are potential sources of alternative treatments and phytochemicals have a huge potential in drug discovery and therapy. Several studies have investigated the use of natural compounds to treat trichomoniasis $[17,18]$. Among such compounds, the polyphenols resveratrol (RESV) and curcumin (CUR) have been reported to display activity against T. vaginalis $[19,20]$. The rhizomes of the perennial plant Curcuma longa (Zingiberaceae) include in their composition curcuminoids (polyphenolic pigments) such as CUR, demethoxycurcumin and bis-methoxycurcumin, as well as volatile oils, sugars, proteins and resins; however, CUR (diferuloylmethane) is generally the main polyphenol found in turmeric and is generally considered the most active component, to which the main pharmacological activities are attributed [21]. It can act as an antioxidant, reacting directly with ROS and RNS and inducing expression of antioxidant proteins, and it can also act as an anti-inflammatory and antiparasitic agent [22-24]. In addition to its scavenging properties, CUR can chelate positively charged metals, such as iron, found at the active sites of several proteins [25]. This is an important factor in the growth and metabolism of T. vaginalis [26,27].

CUR also has anti-inflammatory properties and can inhibit glucocorticoid receptor (mGR) transcription [28], which mediates the transcription of target genes by affecting its phosphorylation status [29]. Likewise, CUR has been reported to regulate the signaling of another transcription factor, NF- $\mathrm{B}$, which is involved in cytokine expression [30,31]. CUR thus modulates the host immune response and affects parasite survival.

CUR is approved for use by the Food and Drug Administration and the Joint FAO/WHO Expert Committee on Food Additives, and relatively high dose tolerance without side effects has been reported [32].

In the present study, we searched for molecular targets on which CUR can act and that explain the antiparasitic effect of the compound. We also investigated the influence of CUR on molecules that are key to parasite survival (enzymes implicated in hydrogenosomal metabolism) and host invasion (proteinases). In addition, we investigated the modulatory role of CUR on the pro-inflammatory response induced by T. vaginalis proteinases in a mice macrophage model.

\section{Results}

\subsection{In Vitro Antiparasitic Effect of Curcumin}

At a concentration of $100 \mu \mathrm{M}, \mathrm{CUR}$ caused a significant decrease in the in vitro growth of T. vaginalis from the first day of culture (Figure 1), relative to control without CUR. It thus displayed cytostatic activity, with an $\mathrm{IC}_{50}$ of about $117 \pm 7 \mu \mathrm{M}$ on the first day; however, the inhibitory effect decreased on the second day of culture, with an $\mathrm{IC}_{50}$ of $173 \pm 15 \mu \mathrm{M}$. DMSO did not affect parasite growth. 


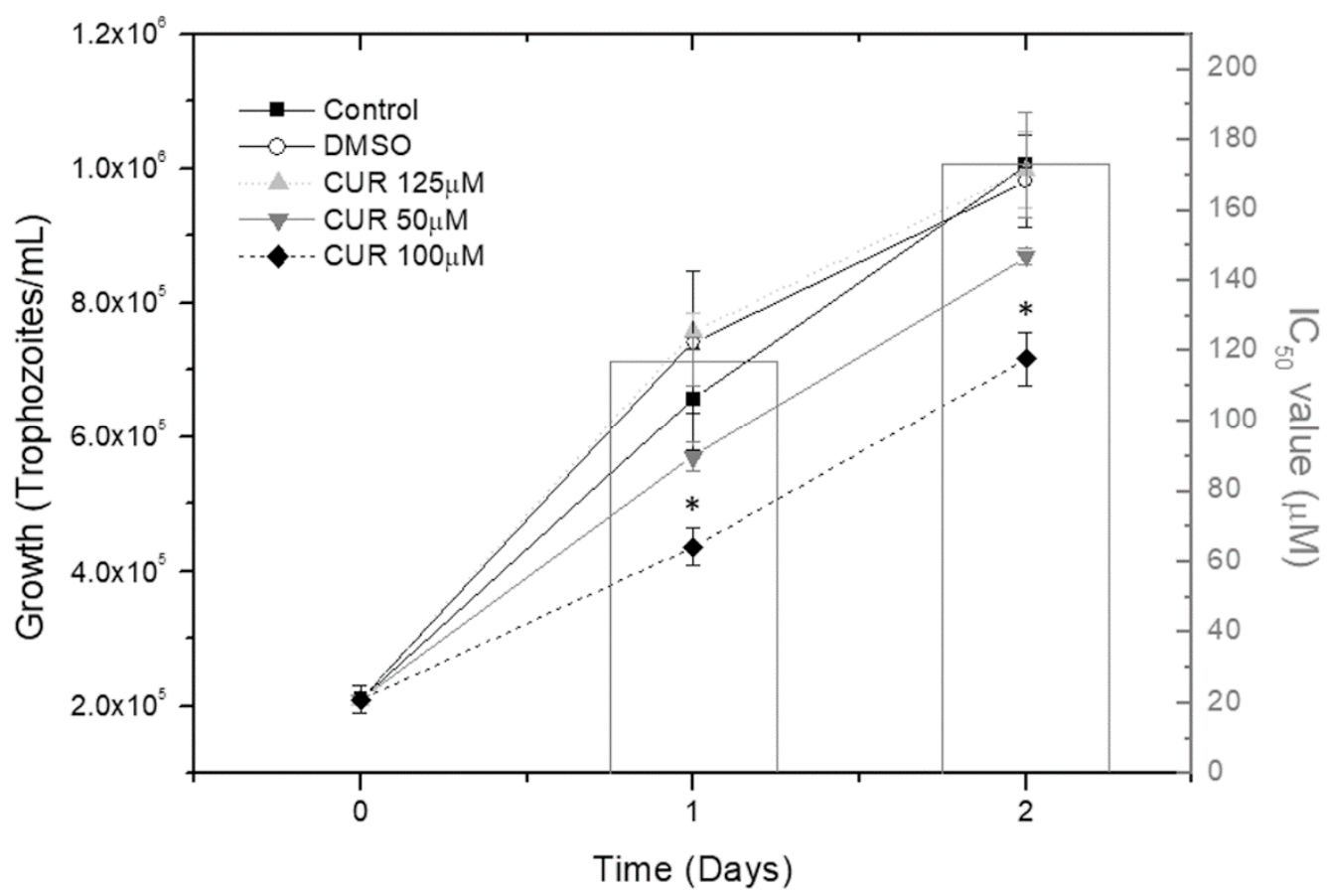

Figure 1. Antiparasitic effect of curcumin (CUR). Growth rate of T. vaginalis trophozoites cultured in vitro in MDM with different doses of CUR (50, 100 and $125 \mu \mathrm{M})$ at $35{ }^{\circ} \mathrm{C}$ in a container under vacuum. The highest concentration of DMSO used in CUR solutions, was added alone to some wells, as a control. Data were obtained by counting the cells with a hemocytometer on 2 consecutive days $(n=5)\left({ }^{*} p<0.05\right)$. Bars indicate the $\mathrm{IC}_{50} \pm$ standard error on day $1(117 \pm 7 \mu \mathrm{M})$ and on day 2 $(173 \pm 15 \mu \mathrm{M})$ of culture.

\subsection{Influence of Curcumin on Pyruvate-Ferredoxine Oxidoreductase (PfoD) Gene Expression and the} Hydrogenosomal Membrane Potential $(\Delta \Psi \mathrm{m})$

At a concentration of $100 \mu \mathrm{M}$, CUR produced significant upregulation of the mRNA expression levels of the PfoD hydrogenosomal enzyme; however, lower doses of the polyphenol did not have any effect on the activity (Figure 2A).

(A)

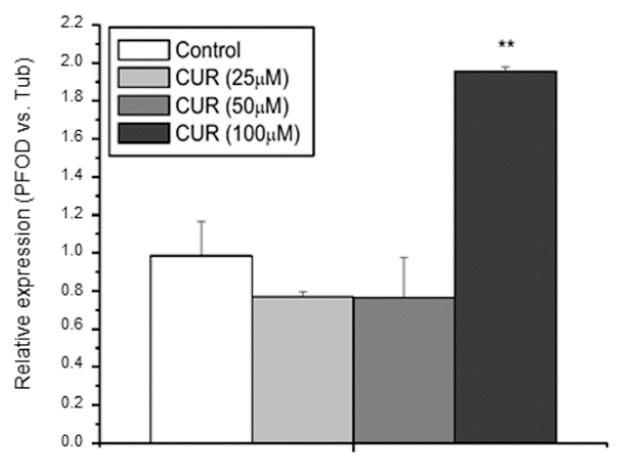

(B)

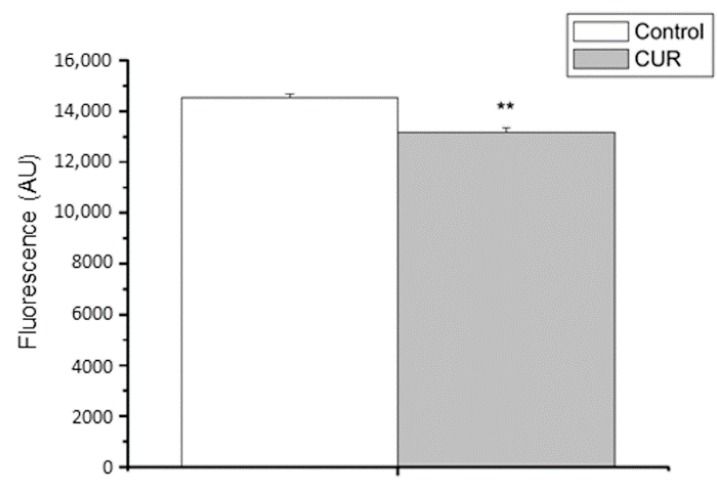

Figure 2. Effect of curcumin (CUR) on energy metabolism in T. vaginalis. (A) Effect of CUR on the T. vaginalis hydrogenosomal enzyme pyruvate-ferredoxin oxidorreductase (PfoD) mRNA expression levels, as revealed by RT-qPCR. Data are expressed relative to T. vaginalis $\beta$-tubulin mRNA expression levels $(n=3)\left({ }^{* *} p<0.01\right)$. (B) Effect of CUR on hydrogenosomal membrane potential $(\Delta \Psi \mathrm{m})$, as revealed by JC-1 fluorescent probe, on T. vaginalis trophozoites incubated for $2 \mathrm{~h}$ under microaerobic conditions in MDM with $100 \mu \mathrm{M}$ CUR. Untreated T. vaginalis trophozoites were included as control. Data are expressed in fluorescence arbitrary units (AU). $(n=5)(* * p<0.01)$. 
The fluorescent probe JC- 1 was used to analyze the effect of CUR $(100 \mu \mathrm{M})$ on $\Delta \Psi \mathrm{m}$ levels. The hydrogenosomal membrane potential levels decreased significantly after incubation for $2 \mathrm{~h}$ with the polyphenol in MDM (Figure 2B).

\subsection{Impact of Curcumin on Parasite Proteolytic Activity}

The proteolytic activity of $T$. vaginalis was altered by addition of CUR, as revealed by qualitative analysis of the proteolytic banding pattern in the SDS-PAGE-gelatin assay (Figure 3A). The pattern of the bands with proteolytic activity was very similar in treated and untreated samples; however, dark bands, which represent proteolytic activity, were wider in untreated samples, as readily visualized on the bands situated at about $50 \mathrm{kDa}$.

Quantitative analysis by use of a gelatin-FITC fluorescence proteolytic assay revealed a significant decrease in proteolytic activity levels in the CUR treated extracts (Figure 3B), consistent with the previous results.

(A)

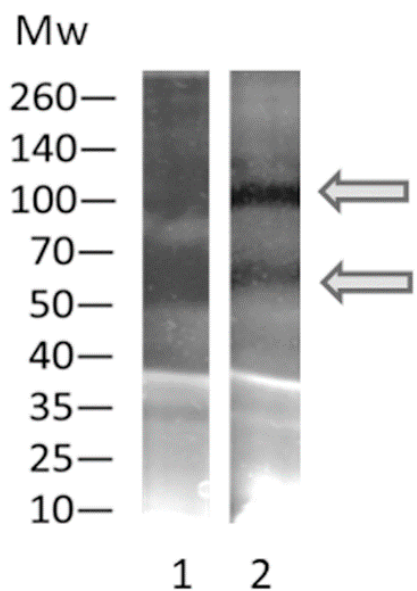

(B)

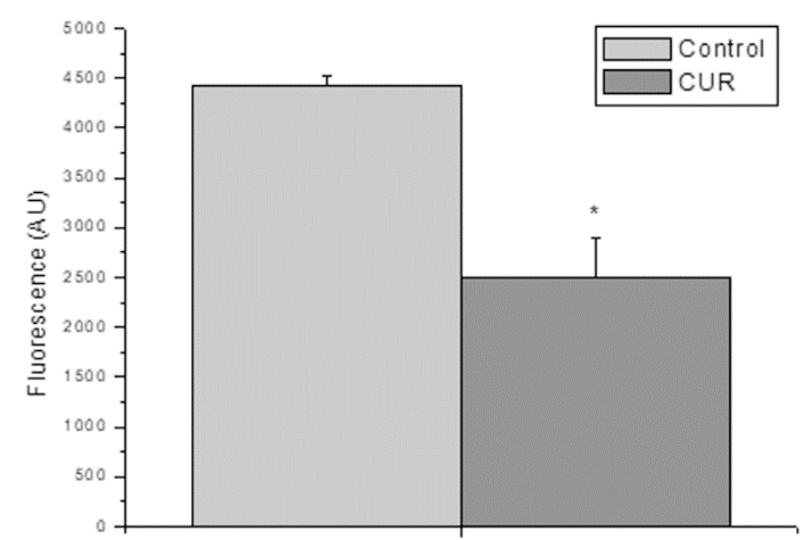

Figure 3. Effects of curcumin (CUR) on parasite proteolytic activity. (A) SDS-PAGE-gelatin analysis of protease activity in T. vaginalis total protein extracts treated for $24 \mathrm{~h}$ with (2) or without (1) CUR (50 $\mu \mathrm{M})$. Gel strips were incubated for $12 \mathrm{~h}$ at $37^{\circ} \mathrm{C}$ with DTT. Proteolytic activity is shown in black in the picture. Arrows indicate bands showing a decrease in proteolytic activity relative to untreated samples. $\mathrm{Mw}$, molecular weight markers (kDa). (B) Quantitative analysis of proteolytic activity measured by a fluorimetric assay with gelatin-FITC as an enzymatic substrate. Data are expressed in fluorescence arbitrary units (AU) $(n=5, * p<0.05)$.

2.4. Influence of Curcumin on the Pro-Inflammatory Processes Induced by Lipopolysaccharide (LPS) and T. vaginalis Proteinases in Immune Cells

We initially investigated the effect of CUR on production of NO (a proinflammatory mediator derivative of oxidative stress) in mouse RAW 264.7 macrophages stimulated with T. vaginalis proteinases or with bacterial LPS (generated during bacterial vaginitis). CUR produced significant inhibition of NO production in both types of stimulated cells without affecting cell viability and cytotoxicity (see supplementary material, Figure S1). Inhibition was even higher than that generated by the NO synthase inhibitor LNMA (Figure 4).

We also investigated the effect of the CUR on gene expression of cellular mediators of inflammation such as the proinflammatory cytokines TNF $\alpha$ and IL-1 $\beta$ in RAW 264.7 mouse macrophages stimulated with bacterial LPS or with the parasite proteinases (Figure 5). The results indicate that the CUR $(100 \mu \mathrm{M})$ caused significant inhibition of the proinflammatory cytokine TNF $\alpha$ in cells stimulated with LPS or with parasite proteinases (Figure 5A). At the same concentration, CUR also strongly inhibited IL-1 $\beta$ expression in LPS-stimulated macrophages; however, the T. vaginalis proteases generated much lower 
levels of mRNA than those generated by LPS, although in this case the inhibition of IL-1 $\beta$ expression by CUR was also significant (Figure 5B).

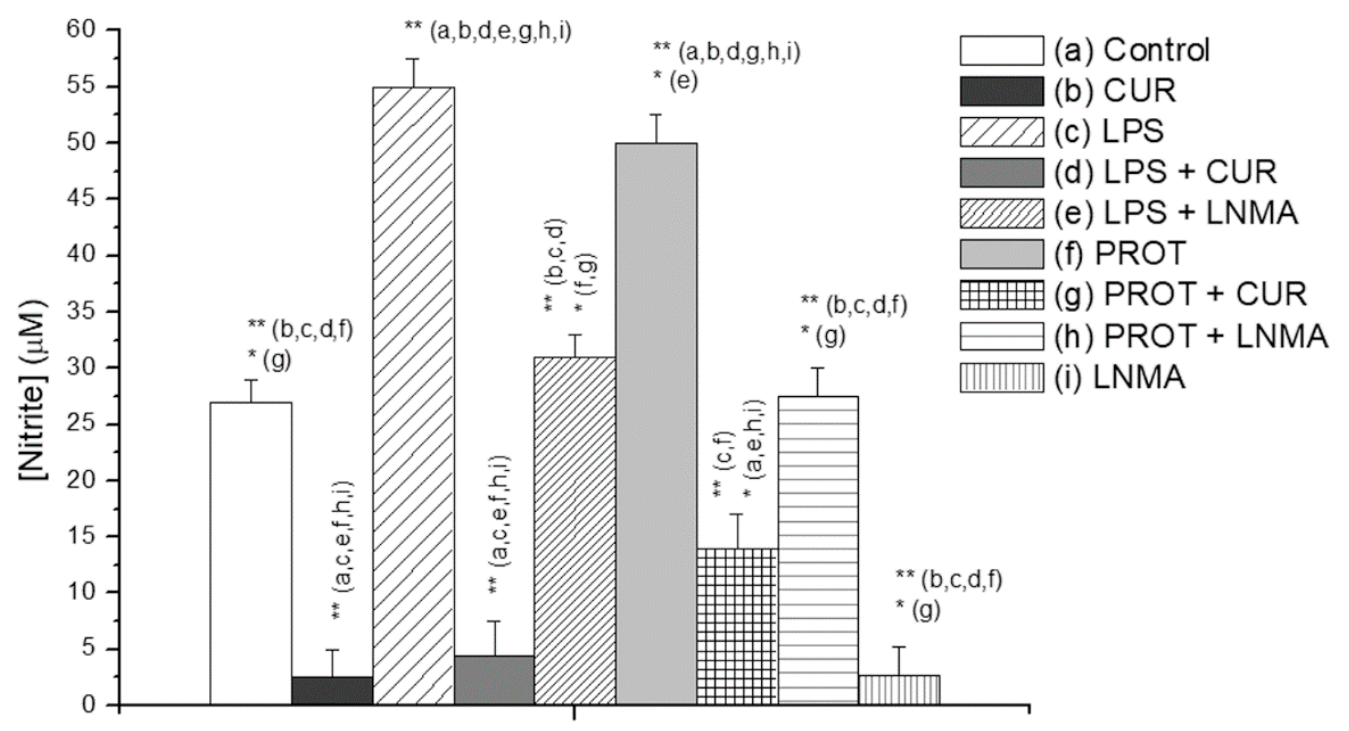

Figure 4. Effect of curcumin (CUR, $100 \mu \mathrm{M})$ on nitric oxide (NO) production. NO production was determined in RAW 267.4 cells after $24 \mathrm{~h}$ incubation with the proinflammatory stimuli lipopolysaccharide (LPS, $100 \mathrm{ng} / \mathrm{mL}$ ) and proteases from T. vaginalis $(50 \mu \mathrm{g} / \mathrm{mL})$. Data represent the nitrite concentration in $\mu \mathrm{M}$ units, measured by spectrophotometry and extrapolated from a regression line constructed for known concentrations of nitrite. The inhibitor of NO synthase LNMA was added (at $250 \mu \mathrm{M}$ ) to control for the inhibitory effect; $(n=5)\left({ }^{*} p<0.05 ;{ }^{* *} p<0.01\right)$.

(A)

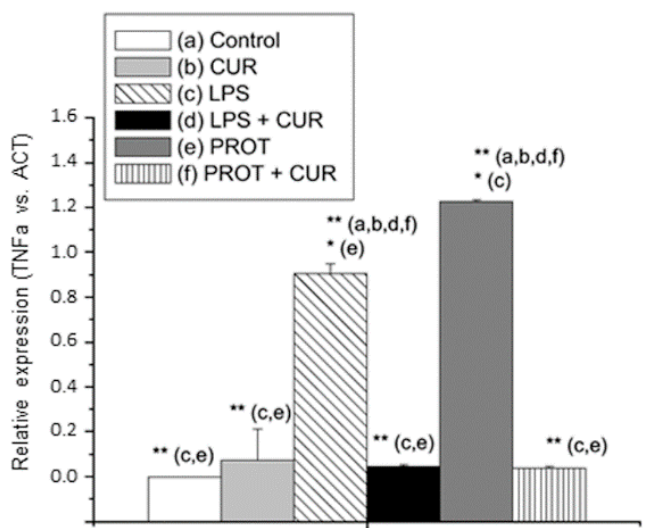

(B)

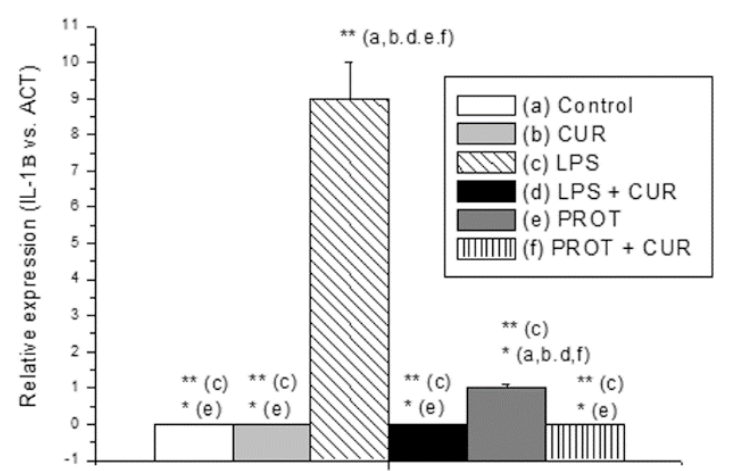

Figure 5. Relative mRNA expression of the genes of proinflammatory cytokines, quantified by RT-qPCR. Relative expression of RAW 267.4 cells TNF $\alpha$ (A) and IL-1 $\beta$ (B) genes after 24 h incubation with $T$. vaginalis proteases, and LPS or CUR. Data are expressed in relative expression units normalized against the housekeeping $\alpha$-actine (ACT) gene mRNA levels $(n=3)$. Asterisks indicate statistically significant differences $\left({ }^{*} p<0.05 ;{ }^{* *} p<0.01\right)$ relative to the control. CUR: curcumin $100 \mu \mathrm{M}$; LPS: lipopolysaccharide $100 \mathrm{ng} / \mathrm{mL}$; PROT: proteases $100 \mu \mathrm{g} / \mathrm{mL}$.

\subsection{Effects of Curcumin on Other Mediators of Inflammation in Macrophages Stimulated with} Lipopolysaccharide (LPS) and Proteinases of T. vaginalis

Finally, we analyzed the effect of CUR on mRNA and protein expression of the genes encoding the glucocorticoid receptor $\mathrm{mGR}$ and the heat shock protein Hsp70. In both cases, RAW 264.7 macrophages were stimulated with LPS or T. vaginalis proteinases (see Figure 6). At a concentration of $100 \mu \mathrm{M}$, 
CUR caused significant inhibition of mGR gene expression, mRNA and protein levels in stimulated cells (Figure 6A,C); however, the polyphenol had the opposite effect on Hsp70 gene expression, inducing increases in mRNA and protein levels (Figure 6B,D).

(A)

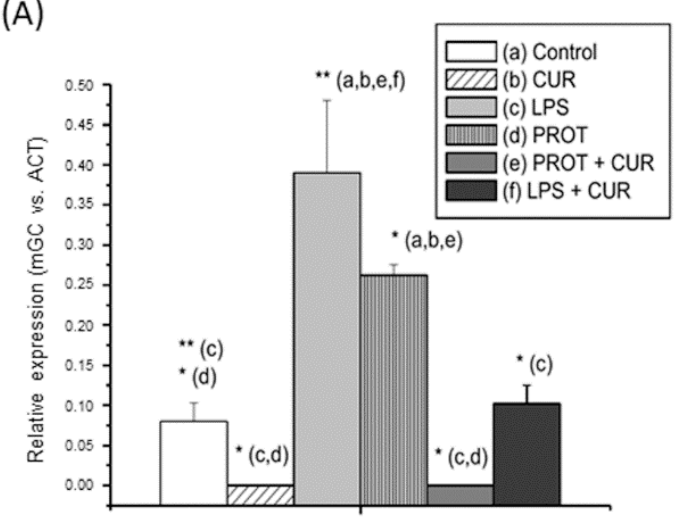

(C)

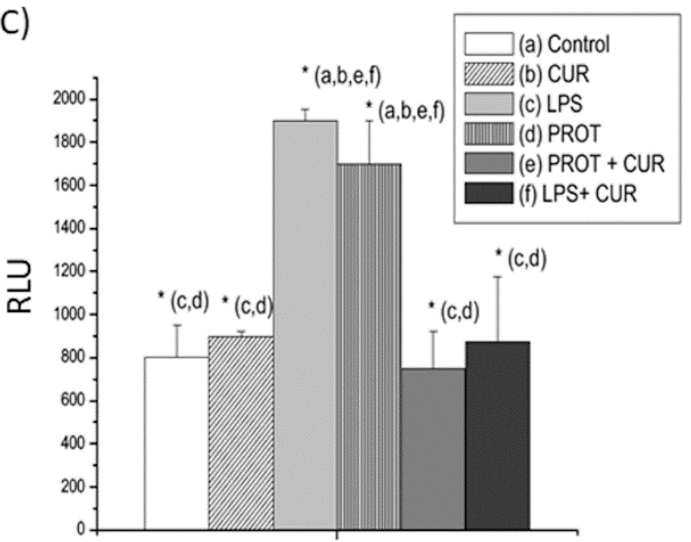

(B)

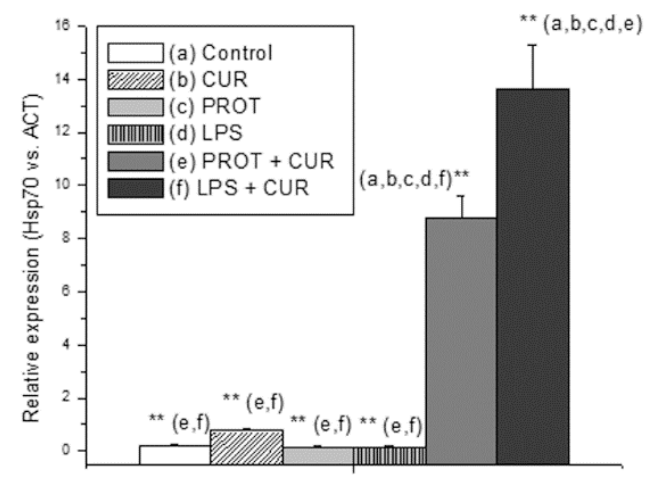

(D)

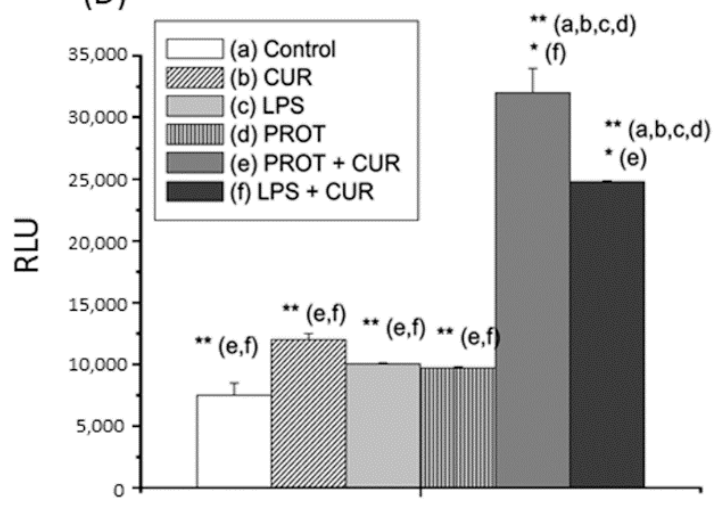

Figure 6. Influence of curcumin (CUR) on expression of glucocorticoid receptor (mGR) and the chaperone heat shock protein 70 (Hsp70). Assays were performed by RT-qPCR (RNA) or ELISA (RAW 267.4 cell protein extracts) and obtained after incubation for $24 \mathrm{~h}$ with the different treatments: T. vaginalis proteinases (PROT $(50 \mu \mathrm{g} / \mathrm{mL}))$, lipopolysaccharide (LPS $(100 \mathrm{ng} / \mathrm{mL}))$ and CUR $(100 \mu \mathrm{M})$. Data indicate inhibition of the upregulation of mGR protein and mRNA expression levels driven by parasite proteinases in the presence of CUR (A,C, respectively). Nevertheless, expression of Hsp70 protein and mRNA increased in the presence of the polyphenol (B,D, respectively). For RT-qPCR assays, data are expressed in relative values normalized relative to actin (ACT) gene expression $(n=3)$ $\left({ }^{*} p<0.05 ;{ }^{* *} p<0.01\right)$. For ELISA assays, all data are expressed as means \pm standard errors of luminescence measured in relative light units (RLU) $(n=3)$. ${ }^{*} p<0.05 ;{ }^{* *} p<0.01$.

\section{Discussion}

Finding alternative treatments for trichomoniasis is important as several strains of T. vaginalis are known to be resistant to MDZ, the most common drug used to treat the disease. The present findings show that CUR exerts an in vitro antiparasitic effect on T. vaginalis, as recently reported for other strains of T. vaginalis [20]; however, the mechanisms underlying the effects of the polyphenol on molecular activity, which would help explain the antiparasitic activity, are not known.

Iron is an essential metal required by many organisms as a cofactor in some biochemical activities that may be essential for parasite survival in the host, such as virulence factors [3]. The hydrogenosome of Trichomonas is characterized by the presence of iron-sulphur (FeS) cluster-containing enzymes such as pyruvate: ferredoxin oxidoreductase (PfoD), which is regulated by iron [26,27,33]. We observed upregulation of mRNA expression levels in T. vaginalis trophozoites treated with CUR, and it is therefore possible that the antiparasitic effect of CUR on T. vaginalis involves Fe transport, as CUR has 
been described as a metal chelator [25]. CUR may also affect the fermentative energetic metabolism of T. vaginalis as a result of its antioxidant properties, because it acts via the induction of hydrogenosomal dysfunction, as revealed by use of a JC-1 probe to study the hydrogenosomal membrane potential levels, which were downregulated by CUR and which may be a signal of cellular death.

Some of the parasite proteins related to cellular death and apoptosis are proteinases [2,34]. Experimental animals inoculated with whole T. vaginalis preparations produced antibody to many proteinases, indicating the immunogenic nature of trichomonad proteinases and their importance in parasite virulence and pathogenesis [35]. As with other parasites, T. vaginalis proteinases have been described as virulence factors, and the chemotherapeutic potential of proteinase inhibitors has been highlighted $[9,34,36,37]$. CUR has been reported to prevent increased proteolytic activity in mice and rat muscle [38]. In this case the anti-inflammatory properties of CUR [39] act on parasite proteolytic activity, particularly on the production of $\mathrm{NO}$ and as modulator of the gene expression of the proinflammatory cytokines, TNF $\alpha$ and IL-1 $\beta$ [40], induced by parasite proteinases.

Nitric oxide (NO) production by the NO-synthase isoform NOS-II has been specifically described to play an important role as an effector of macrophage-mediated cytotoxicity and immune modulation against numerous parasites, including T. vaginalis [41,42]. Some investigators attribute the NO cytotoxicity to the iron-scavenging properties of the nitrogen by-products, resulting in iron depletion and the consequent inactivation of iron-requiring molecules [41]. However, other investigators attribute NO cytotoxicity to the inhibition of cysteine proteinases of several parasites, such as Plasmodium falciparum, Trypanosoma cruzi and Leishmania infantum, by NO-releasing compounds [42]. The antioxidant properties of CUR have been defined as the ability of the compound to scavenge NO [43]. We observed this effect in mouse peritoneal macrophages in which NO production was activated by the addition of LPS and T. vaginalis proteinases, and it was even more pronounced than that caused by the NO-synthase inhibitor LNMA.

Interleukin $1 \beta(\mathrm{IL}-1 \beta)$ and tumor necrosis factor $\alpha(\mathrm{TNF} \alpha)$ are important proinflammatory cytokines that can trigger inflammatory signaling pathways by activating nuclear factor $\kappa \mathrm{B}(\mathrm{NF}-\kappa \mathrm{B})$ (a transcription factor that can be stimulated by stress). CUR, like other plant-derived phytochemicals, has the ability to target the NF- $\mathrm{B}$ signaling pathway $[23,30,44-46]$. We observed that addition of CUR significantly downregulated expression of $\mathrm{TNF} \alpha$ and IL-1 $\beta$ genes in macrophages stimulated with LPS or T. vaginalis proteinases.

The glucocorticoid receptor (mGR) is also associated with the chaperone complex. This ligand-dependent transcription factor mediates developmental and metabolic processes in response to glucocorticoids and acts as a regulator of the promoters of glucocorticoid responsive genes as well as other transcription factors involved in inflammatory responses and cellular proliferation. mGR is bound to the chaperone complex in its cytoplasmic state, before ligand binding, and upon ligand binding it translocates to the nucleus where it binds specific DNA sequences and modulates transcription [29]. mGR-mediated transcription has been found to be inhibited by CUR via phosphorylation [28,29]. In the present study, we found that the addition of CUR to mice macrophage cells inhibited upregulation of mGR protein and gene expression levels by LPS and T. vaginalis proteinases, again indicating the anti-inflammatory properties of this polyphenol.

TNF $\alpha$ and IL-1 $\beta$ are negatively regulated by heat shock factor (HSF-1), a transcription factor that drives the increase in heat shock proteins (Hsps) in response to stress. The relationship between $N F k B$, Hsps and HSF-1 is complicated, and activation of NFKB increases significantly as HSF-1 decreases. Consequently, independently of the activation of Hsps expression, HSF-1 inhibits transcription of a number of pro-inflammatory genes and modulates the activation of NFKB [45,47]. Heat shock response supports cells by regulating physiological homeostasis under stress conditions, such as in a pathological disorder. CUR, which downregulates the pro-inflammatory and proliferative capacities of $T$. vaginalis, induces a heat shock response, as reported in several organisms, including human cells $[46,48-50]$. Some natural compounds are known to be capable of activating chaperone induction and thus interfering in cell survival $[46,50]$. In the present study, we observed an increase in Hsp70 
protein and gene expression levels in response to addition of CUR along with stress stimuli such as T. vaginalis proteinases and LPS.

In conclusion, CUR exerts an in vitro anti-parasitic effect on $T$. vaginalis by affecting the hydrogenosomal function. CUR also exerts an anti-inflammatory effect on the host, via the pro-inflammatory effect of the parasite proteinases, demonstrating the potential suitability of this compound as a treatment for trichomoniasis and for improving the immunopathological effects derived from the disease.

\section{Materials and Methods}

\subsection{Parasites}

Trichomonas vaginalis isolate Tv1 was obtained from a patient with vaginal trichomoniasis attending the gynecology service of the Santiago de Compostela University Hospital Complex (Spain). Isolates were cultured axenically in vitro, in modified Diamond's medium (MDM) containing $2 \%(w / v)$ trypticase, $1 \%(w / v)$ yeast extract, $0.5 \%(w / v)$ maltose, $0.1 \%(w / v)$ L-ascorbic acid, $0.1 \%(w / v)$ L-cysteine, $0.1 \%$ $(w / v) \mathrm{KCl}, 0.1 \%(w / v) \mathrm{KHCO}_{3}, 0.1 \%(w / v) \mathrm{KH}_{2} \mathrm{PO}_{4}, 0.1 \%(w / v) \mathrm{K}_{2} \mathrm{PO}_{4}$ and $0.02 \%(w / v) \mathrm{FeSO}_{4}(\mathrm{pH} 6.2)$ supplemented with $10 \%(v / v)$ heat-inactivated fetal bovine serum, as previously described $[19,51]$. Trophozoites were cultured at $35^{\circ} \mathrm{C}$ in $15-\mathrm{mL}$ sterile tubes completely filled with medium to create an $\mathrm{O}_{2}$ poor environment. Cells were grown to late log phase $\left(1 \times 10^{6}\right.$ to $2 \times 10^{6}$ cells $\left./ \mathrm{mL}\right)$ and harvested by centrifugation $(5 \mathrm{~min}$ at $200 \times g)$ for use in all experiments [19].

\subsection{Culture of Murine Macrophages}

Macrophage-like cell line RAW 264.7, derived from BALB/c mice, was acquired from the American Type Culture Collection (ATCC; cat. N TIB-71). The cells were cultured following the supplier's instructions, in Dulbecco's modified Eagle's medium (Sigma-Aldrich, Madrid, Spain) supplemented with $10 \%$ inactivated fetal bovine serum (FBS) and $1 \%$ of an antibiotic/antimycotic solution (100x) (100 units $/ \mathrm{mL}$ penicillin $\mathrm{G}, 0.1 \mathrm{mg} / \mathrm{mL}$ streptomycin) at $37^{\circ} \mathrm{C}$ in humidified atmosphere containing $5 \%$ $\mathrm{CO}_{2}[52]$.

\subsection{Antiparasitic Activity}

The effect of CUR (Sigma-Aldrich) on the in vitro growth of T. vaginalis was analyzed as previously described (19). Briefly, different concentrations of CUR (50, 100 and $125 \mu \mathrm{M})$ were added to the cell cultures from a $100 \mathrm{mM}$ stock solution prepared in dimethyl sulfoxide (DMSO) and stored in the dark at $-20^{\circ} \mathrm{C}$ until use. Parasites were cultured in sterile 24-well culture plates (Corning, New York, NY, USA) containing $2 \times 10^{5}$ trophozoites/well in MDM with 5 replicates of the different treatments for 2 days at $35^{\circ} \mathrm{C}$ in a container under a vacuum. A control containing the highest concentration of DMSO used was included in the assay. The concentration of trophozoites was determined daily by counting the cells contained in $10 \mu \mathrm{L}$ aliquots of the cell suspensions removed from each well. Cells were counted in a hemocytometer. The in vitro half maximal inhibitory concentrations $\left(\mathrm{IC}_{50}\right)$ (in relation to the antiparasitic activity of CUR) were calculated by regression analysis. An Excel program (Microsoft Office software package) was used to implement the linear regression formula $y=m x+b$, where $m$ is the slope $y_{1}-y_{2} / x_{1}-x_{2}$ and $b$ the intercept value of the line by using the equation: $\mathrm{IC}_{50}=(0.5-\mathrm{b}) \times \log$ dose $/ \mathrm{m}$.

\subsection{Hydrogenosomal Membrane Potential Assay}

The hydrogenosomal $T$. vaginalis membrane potential $(\Delta \Psi \mathrm{m})$ was determined using the JC-1 kit (Molecular Probes) with the cationic fluorescent probe 5,5',6,6'-tetrachloro-1,1', 3,3'-tetraethylbenzimidazolcarbocyanine iodide (JC-1), following the manufacturer's instructions [19]. T. vaginalis trophozoites $\left(5 \times 10^{5}\right.$ trophozoites/100 $\left.\mu \mathrm{L}\right)$ were suspended in culture medium containing $100 \mu \mathrm{M}$ CUR and incubated in 96-well cell culture plates for $2 \mathrm{~h}$ at $37^{\circ} \mathrm{C}$ in a container under anoxic 
conditions. The probe was then added, and the plates were further incubated at $37^{\circ} \mathrm{C}$ in darkness for $30 \mathrm{~min}$. The plates were then centrifuged at $200 \times \mathrm{g}$ for $5 \mathrm{~min}$, to remove CUR, before being washed twice in assay buffer. Finally, fluorescence was measured in a microplate fluorimeter (Fx800, BioTek, Winooski, VT, USA) at excitation/emission wavelengths of 485/535 nm. All experiments were carried out in triplicate and a control without CUR was included to determine the fluorescence produced by spontaneous oxidation. This value was subtracted from the fluorescence emitted by the experimental samples.

\subsection{Proteinase Purification}

The protocol was performed as described by [53], with slight modifications. The T. vaginalis trophozoites were washed three times with PBS and resuspended in equilibration buffer (100 mM $\mathrm{CH}_{3} \mathrm{COONH}_{4}$ and $10 \mathrm{mM} \mathrm{CaCl}_{2}, \mathrm{pH}$ 6.5). The samples were then sonicated on ice in a Branson W-250 sonifier (Branson Ultrasonic Corporation, Danbury, CT, USA), with 8 cycles of 10 pulses (duty cycle of $50 \%$ and out intensity 4 ), followed by centrifugation at $15,000 \times g$ for $10 \mathrm{~min}$. The samples were then filtered $(0.22 \mu \mathrm{m}$, Millipore, Burlington, MA, USA) and applied to a CNBr-activated bacitracin sepharose XK 16/20 column (GE Healthcare, Chicago, IL, USA) connected to a protein purification system (AKTAprim plus; GE Healthcare, USA). The column was washed with washing buffer (100 mM $\mathrm{CH}_{3} \mathrm{COONH}_{4}, \mathrm{pH}$ 6.5) until the $280 \mathrm{~nm}$ absorbance was basal. Elution buffer containing $100 \mathrm{mM}$ $\mathrm{CH}_{3} \mathrm{COONH}_{4}, 1 \mathrm{M} \mathrm{NaCl}$ and 25\% (v/v) 2-isopropanol pH 6.5 was then added. Eluted samples were collected in $2.5 \mathrm{~mL}$ fractions until the OD at $280 \mathrm{~nm}$ was basal. Finally, samples were dialyzed against equilibration buffer, concentrated by ultrafiltration with Amicon Ultra $10 \mathrm{~K}$ centrifugal filter devices (Millipore, MA, USA) and stored in PBS $0.15 \mathrm{M}$ at $-80^{\circ} \mathrm{C}$. The protein concentration was determined by the method of Bradford [54] with a Bio-Rad Protein Assay kit (Bio-Rad Laboratories, Hercules, CA, USA) and with bovine serum albumin (Sigma-Aldrich) as standard [55].

\subsection{SDS-PAGE-Gelatin Assay}

The effect of CUR on the activity of parasite proteinases was measured by sodium dodecyl sulphate polyacrylamide gel electrophoresis (SDS-PAGE) with $0.1 \%$ gelatin in 10\% SDS linear gels under non-reduced conditions (without DTT) [53,55]. Parasites were cultured with or without a $50 \mu \mathrm{M}$ CUR solution for $24 \mathrm{~h}$ and then washed twice in PBS and sonicated on ice in a Branson W-250 sonifier (Branson Ultrasonic Corporation, USA), with 8 cycles of 10 pulses (duty cycle of $50 \%$ and out intensity 4). The samples were then centrifuged at $20,000 \times g$ for 15 min at $4{ }^{\circ} \mathrm{C}$, and $6 \times$ loading buffer (containing $62 \mathrm{mM}$ Tris- $\mathrm{HCl}$ buffer, $\mathrm{pH}$ 6.8, 2\% SDS and 10\% glycerol) was added to the resultant supernatant. The protein concentration in the extract was determined by the Bradford method [53], as described above. The samples were electrophoresed in a vertical electrophoresis system (Hoeffer, GE Healthcare, USA) for $45 \mathrm{~min}$ at $200 \mathrm{~V}$ with electrophoresis buffer (25 mM Tris, $190 \mathrm{mM}$ glycine and 1\% SDS, pH 8.3). The gel was cut into strips to separate different samples, which were then incubated for $30 \mathrm{~min}$ in a $2.5 \%$ Triton X-100 (v/v) solution and then in $0.1 \mathrm{M}$ citrate buffer, $\mathrm{pH} 4$ and $0.1 \mathrm{mM}$ DTT, for $12 \mathrm{~h}$ at $37^{\circ} \mathrm{C}$ with constant shaking, to enable development of the proteolytic activity of the T. vaginalis proteinases on the gelatin. Finally, the gels were stained with Thermo Scientific GelCode Blue Safe Protein Stain (Pierce, Thermo Fisher Scientific, Whalthan, MA, USA) to visualize the non-stained bands corresponding to lysed gelatin. Proteolytic bands appeared as clear bands on the stained blue background after destaining with water $[53,55]$.

\subsection{Gelatin-FITC Proteolytic Activity}

The quantitative effect of CUR on T. vaginalis proteolytic activity was assayed by measuring the hydrolytic capacity of the proteinases on a solution containing a protein substrate (gelatin) conjugated with a fluorescent ligand (fluorescein isothiocyanate; FITC). For the assay, FITC was dissolved with the gelatin in the same proportion in $\mathrm{Na}_{2} \mathrm{HPO}_{4}$ solution at $\mathrm{pH}$ 9-9.5 and incubated for $1 \mathrm{~h}$ at room temperature. After gelatin and FITC coupling, excess FITC was removed by dialysis against PBS and 
centrifuged at $5000 \times g$ for $10 \mathrm{~min}$ to eliminate precipitated protein. Aliquots were stored at $-20^{\circ} \mathrm{C}$ until use.

Aliquots $(10 \mu \mathrm{L})$ of each lysate (sample with or without treatment with CUR), obtained as indicated above, were incubated with $20 \mu \mathrm{L}$ of PBS and $20 \mu \mathrm{L}$ of gelatin-FITC at $35^{\circ} \mathrm{C}$ for $4 \mathrm{~h}$ in the dark in a moist chamber. After incubation, $120 \mu \mathrm{L}$ of a $0.6 \mathrm{M}$ trichloroacetic acid (TCA) solution was added and the mixture was held at room temperature for $30 \mathrm{~min}$ to enable precipitation of proteins. Finally, samples were centrifuged at $3000 \times \mathrm{g}$ for $10 \mathrm{~min}$ and fluorescence was measured in a fluorimeter (Fl $\times 800$, Biotek, USA) at $488 / 520 \mathrm{~nm}$ excitation/emission. Three replicates of each sample were prepared.

\subsection{Assay of Nitrite Production}

Production of NO by RAW 264.7 cells after culture for $48 \mathrm{~h}$ with $T$. vaginalis proteinases and CUR treatments was measured by the Griess reaction [56]. Supernatants from the cell cultures $(100 \mu \mathrm{L})$ were incubated with $100 \mu \mathrm{L}$ of Griess reagent containing $1 \%$ sulfanilamide, $0.1 \%$ $\mathrm{N}$-(1-naphtyl)-ethylendiamine dihydrochloride and $2.5 \% \mathrm{H}_{3} \mathrm{PO}_{4}$ at room temperature for $10 \mathrm{~min}$. The absorbance was measured at $530 \mathrm{~nm}$ in a microplate reader (Titertek Multiscan, Flow Laboratories, Sunnyvale, CA, USA). The NO concentration was calculated with reference to a standard curve prepared with different concentrations of $\mathrm{NaNO}_{2}$ (1-200 $\mu \mathrm{M}$ in RAW 264.7 culture medium). Each treatment was prepared in triplicate. The NO synthase inhibitor LNMA $(\mathrm{N}(\mathrm{G})$ monomethyl-L-arginine monoacetate at $250 \mu \mathrm{M}$ was added as a negative control of NO production and $100 \mathrm{ng} / \mathrm{mL}$ LPS was added as a positive control for NO production [52,57].

\subsection{Real-Time Quantitative Reverse Transcriptase-Polymerase Chain Reaction (RT-qPCR)}

The RT-qPCR assay was performed as previously described [19], with minor modifications. After treatment for $24 \mathrm{~h}$ with CUR and/or lipopolysaccharide (LPS) and proteinases (in the case of macrophages), total RNA from T. vaginalis trophozoites ( $10^{7}$ cells/sample) or from RAW 264.7 cells were isolated with NucleoSpin RNA kit (Macherey-Nagel, Düren, Germany), following the manufacturer's instructions. Purified RNA was treated with DNase I (RNase free, Thermo Fisher Scientific, Whalthan, MA, USA) and the purity and final concentration were estimated in a NanoDrop ND-1000 spectrophotometer (Thermo Fisher Scientific). cDNA was synthesized ( $25 \mu \mathrm{L} /$ reaction mixture) with $1.25 \mu \mathrm{M}$ random hexamer primers (Roche, Basel, Switzerland), $250 \mu \mathrm{M}$ deoxynucleosides triphosphate (dNTPs), each, $10 \mathrm{mM}$ dithiothreitol (DTT), $20 \mathrm{U}$ of RNase inhibitor, $2.5 \mathrm{mM} \mathrm{MgCl}_{2}$ and 200U of MMLV (Moloney murine leukemia virus) reverse transcriptase (Promega, Madison, WI, USA) in reaction buffer containing $30 \mathrm{mM}$ Tris and $20 \mathrm{mM} \mathrm{KCl}$ (pH 8.3). Two micrograms of RNA was added per sample.

The qPCR reaction for $T$. vaginalis samples was performed with gene-specific primers for the pyruvate-ferredoxin oxidoreductase $D(p f o D)$ gene (forward/reverse primer pair 5'-TCTCCGTTCTTGATCGTTCC-3'/5' -TGTTGTCGAAGACAGCCTG-3') and for the $\beta$-tubulin(Tub) gene (forward/reverse primer pair $5^{\prime}$-TACTCCATCGTCCCATCTCC-3'/5' -CCGGACATAACCATGGAAAC-3'), used as a housekeeping gene, to normalize data.

For mice expression assays, the following primer sequences were used: tumor necrosis factor $\alpha(\mathrm{TNF} \alpha)$ : forward/reverse primer pair $5^{\prime}$-AGCCCCCAGTCTGTATCCTT $-3^{\prime} / 5^{\prime}$ - CTCCCTTTGCAGAACTCAGG-3', interleukine-1 $\beta$ (IL-1 $\beta$ ) forward/reverse primer pair $5^{\prime}$ GCCCATCCTCTGTGACTCAT-3'/5'-AGGCCACAGGTATTTTGTCG -3'; glucocorticoid receptor (mGC) forward/reverse primer pair 5' - AGGCCGCTCAGTGTTTTCTAA-3'/TTACAGCTTCCA CACGTCAGC-3'; chaperones Hsp70 (Hsp70) forward/reverse primer pair 5' - CATCATCAATGAGCC CACAG- $3^{\prime} / 5^{\prime}$-TCTTGTGTTTGCGCTTGAAC- $3^{\prime}$ and $\beta$-actin (ACT) forward/reverse primer pair 5'-AGCCATGTACGTAGCCATCC-3'/5'-CTCTCAGCTGTGGTGGTGAA- ${ }^{\prime} ;$ ACT was used to normalize data, which were expressed in relative arbitrary units (RLU).

Primer pairs were designed and optimized with the Primer 3 Plus program (http://www. bioinformatics.nl/cgibin/primer3plus/primer3plus.cgi) with a Tm of $60{ }^{\circ} \mathrm{C}$ The values show the mean \pm the standard error (SE) of the relative expression in arbitrary units of three trials. 
The qPCR mixtures $(10 \mu \mathrm{L})$ were prepared with a reaction mix already containing the assay buffer, dNTPs and SYBR Green (Maxima SYBR Green qPCR Master Mix, Thermo Scientific). Primer pairs were used at a final concentration of $300 \mathrm{nM}$ and $1 \mu \mathrm{L}$ of cDNA was added per well, and the $10 \mu \mathrm{L}$ final volume was completed with RNAse free distilled $\mathrm{H}_{2} \mathrm{O}$.

The qPCR reaction was conducted at $95^{\circ} \mathrm{C}$ for $5 \mathrm{~min}$ followed by 40 cycles of $10 \mathrm{~s}$ at $95^{\circ} \mathrm{C}$ and $30 \mathrm{~s}$ at $60^{\circ} \mathrm{C}$. Melting curve analysis was then carried out at $95^{\circ} \mathrm{C}$ for $15 \mathrm{~s}, 55^{\circ} \mathrm{C}$ for $15 \mathrm{~s}$, and $95^{\circ} \mathrm{C}$ for $15 \mathrm{~s}$. The qPCR product specificity and size were confirmed by gel electrophoresis with $2 \%$ agarose [19]. All reactions were performed in a real time PCR system, Eco Real-time PCR system (Illumina, San Diego, CA, USA). Relative quantification of gene expression was determined by $2^{-\Delta \Delta C q}$ method [58] in accordance with MIQUE (minimum information guidelines for publishing real-time quantitative PCR experiments) [59].

\subsection{Chemiluminiscent Enzyme-Linked ImmunoSorbent Assay (ELISA)}

An indirect ELISA was used to detect mGR and Hsp70 antibodies against the crude extract (CE) of RAW 267.4 cells as previously described [60], with minor modifications. The cells were incubated with the different treatments (CUR at $100 \mu \mathrm{M}$, lipopolysaccharide; LPS at $100 \mathrm{ng} / \mathrm{mL}$ and proteinases $50 \mu \mathrm{g} / \mathrm{mL}$ ) for $24 \mathrm{~h}$, collected by scraping, centrifuged at $250 \times \mathrm{g}$ for $5 \mathrm{~min}$ and rinsed in PBS. Ten volumes of Cell Lysis (ProteoJET ${ }^{\text {TM }}$ Cytoplasmic and Nuclear Protein Extraction Kit) containing protease inhibitor cocktail (ProteoBlock ${ }^{\mathrm{TM}}$ Protease Inhibitor Cocktail) were added followed by $0.1 \mathrm{M}$ DTT. The mixture was vortexed for $10 \mathrm{sec}$, placed on ice for $10 \mathrm{~min}$ and vortexed again. Samples were diluted in carbonate-bicarbonate buffer $(\mathrm{pH} 9.6)$ and the protein concentration was estimated by the Bradford method, as described above. The antigen $(1.5 \mu \mathrm{g})$ was then added to 96-well ELISA plates (Iwaki Europe $\mathrm{GmbH}$, Willich, Germany) and incubated overnight at $4{ }^{\circ} \mathrm{C}$. The plates were washed three times with TBS ( $50 \mathrm{mM}$ Tris, $0.15 \mathrm{M} \mathrm{NaCl}$, pH 7.4) and blocked for $1 \mathrm{~h}$ with TBS containing $0.2 \%$ Tween 20 (TBS-T1) and 5\% non-fat dry milk. The plates were then incubated in a microplate shaker at $750 \mathrm{rpm}$ for $30 \mathrm{~min}$ at room temperature with the antibodies (rabbit anti-GR (M-20): sc-1004 and rabbit anti-HSP 70/HSC 70, H-300, Santa Cruz Biotechnology, New York, NY, USA) in a 1:500 dilution (in TBS-T1 containing 1\% non-fat dry milk) and washed five times with TBS containing $0.05 \%$ Tween 20. Bound antibodies were detected with peroxidase (HRP)-conjugated goat anti-rabbit Ig (Dako, Agilent, Santa Clara, CA, USA) diluted 1:1000 in TBS-T1 and incubated in a microplate shaker at $750 \mathrm{rpm}$ for $30 \mathrm{~min}$. The plates were washed five times in TBS before addition of $100 \mu \mathrm{L}$ to each well of enhanced luminol-based chemiluminiscent substrate for detection of HRP (Thermo Fisher Scientific) After 2 min of incubation, luminescence was measured in a multi-detection microplate reader (Biotek, FL $\times 800$ ) in the configuration for luminescence measurements.

\subsection{Statistical Analysis}

Results are expressed as mean values \pm standard error of means (SEM). Data were tested by one-way analysis of variance (ANOVA) followed by a Tukey-Kramer test for multiple comparisons, and differences were considered significant at $p \leq 0.05$.

Supplementary Materials: The following are available online, Figure S1: (A) Microphotographs of RAW 264.7 cells stained with MTT and incubated for $24 \mathrm{~h}$ with curcumin at concentrations between 25-150 $\mu \mathrm{M}$. (B) Quantification of formazan levels produced by RAW 264.7 cells incubated for $24 \mathrm{~h}$ with curcumin at concentrations between 25-150 $\mu \mathrm{M}$.

Author Contributions: Conceptualization, J.M.L. and J.L.; methodology, N.M. and R.A.S.; formal analysis, N.M. and J.M.L.; investigation, N.M. and R.A.S.; resources, J.M.L.; data curation, J.M.L.; writing-original draft preparation, J.M.L. and J.L.; supervision, J.M.L.; funding acquisition, J.M.L. and J.L. All authors have read and agreed to the published version of the manuscript.

Funding: This research was funded by Xunta de Galicia (Spain), grant number ED431C2017/31.

Conflicts of Interest: The authors declare no conflict of interest. 


\section{References}

1. Schwebke, J.R.; Burgess, D. Trichomoniasis. Clin. Microbiol. Rev. 2004, 17, 794-803. [CrossRef] [PubMed]

2. Menezes, C.B.; Frasson, A.P.; Tasca, T. Trichomoniasis are we giving the deserved attention to the most common non-viral sexually transmitted disease worldwide? Microb. Cell (Graz, Austria) 2016, 3, 404-419. [CrossRef] [PubMed]

3. Arroyo, R.; Cárdenas-Guerra, R.E.; Figueroa-Angulo, E.E.; Puente-Rivera, J.; Zamudio-Prieto, O.; Ortega-López, J. Trichomonas vaginalis Cysteine Proteinases: Iron Response in gene expression and proteolytic activity. BioMed Res. Int. 2015, 2015, 946787. [CrossRef] [PubMed]

4. Provenzano, D.; Alderete, J.F. Analysis of human immunoglobulin-degrading cysteine proteinases of Trichomonas vaginalis. Infect Immun. 1995, 63, 3388-3395. [CrossRef] [PubMed]

5. Álvarez-Sánchez, M.E.; Ávila-González, L.; Becerril-García, C.; Fattel-Facenda, L.V.; Ortega-López, J.; Arroyo, R. A novel cysteine proteinase (CP65) of Trichomonas vaginalis involved in cytotoxicity. Microb. Pathog. 2000, 28, 193-202. [CrossRef]

6. Hernández-Gutiérrez, R.; Ávila-González, L.; Ortega-López, J.; Cruz-Talonia, F.; Gómez-Gutierrez, G.; Arroyo, R. Trichomonas vaginalis: Characterization of a 39-kDa cysteine proteinase found in patient vaginal secretions. Exp. Parasitol. 2004, 107, 125-135. [CrossRef]

7. Hernández, H.M.; Sariego, I.; Álvarez, A.B.; Marcet, R.; Vancol, E.; Álvarez, A.; Figueredo, M.; Sarracent, J. Trichomonas vaginalis $62 \mathrm{kDa}$ proteinase as a possible virulence factor. Parasitol. Res. 2011, 108, 241-245. [CrossRef]

8. Ma, L.; Meng, Q.; Cheng, W.; Sung, Y.; Tang, P.; Hu, S.; Yu, J. Involvement of the GP63 protease in infection of Trichomonas vaginalis. Parasitol. Res. 2011, 109, 71-79. [CrossRef]

9. Mercer, F.; Johnson, P.J. Trichomonas vaginalis: Pathogenesis, symbiont interations, and host cell immune response. Trends Parasitol. 2018, 34, 683-693. [CrossRef]

10. Cárdenas-Guerra, R.E.; Arroyo, R.; Rosa de Andrade, I.; Benchimol, M.; Ortega-López, J. The iron-induced cysteine proteinase TvCP4 plays a key role in Trichomonas vaginalis haemolysis. Microbes Infect. 2013, 15, 958-968. [CrossRef]

11. Rendón-Gandarilla, F.J.; Ramón-Luing, L.D.L.; Ortega-López, J.; Rosa de Andrade, I.; Benchimol, M.; Arroyo, R. The TvLEGU-1, a legumain-like cysteine proteinase, plays a key role in Trichomonas vaginalis cytoadherence. Biomed. Res. Int. 2013, 2013, 561979. [CrossRef] [PubMed]

12. Kalia, N.; Singh, J.; Kaur, M. Immunopathology of Recurrent Vulvovaginal Infections: New Aspects and Research Directions. Front. Immunol. 2019, 10, 2034. [CrossRef] [PubMed]

13. Quon, D.V.; d'Oliveira, C.E.; Johnson, P.J. Reduced transcription of the ferredoxin gene in metronidazole-resistant Trichomonas vaginalis. Proc. Natl. Acad. Sci. USA 1992, 89, 4402-4406. [CrossRef]

14. Samarawickrema, N.A.; Brown, D.M.; Upcroft, J.A.; Thammapalerd, N.; Upcroft, P. Involvement of superoxide dismutase and pyruvate:ferredoxin oxidoreductase in mechanisms of metronidazole resistance in Entamoeba histolytica. J. Antimicrob. Chemother. 1997, 40, 833-840. [CrossRef]

15. Dingsdag, S.A.; Hunter, N. Metronidazole: An update on metabolism, structure-cytotoxicity and resistance mechanisms. J. Antimicrob. Chemother. 2018, 73, 265-279. [CrossRef] [PubMed]

16. Kulda, J. Trichomonads, hydrogenosomes and drug resistance. Int. J. Parasitol. 1999, 29, 199-212. [CrossRef]

17. Palmeira-de-Oliveira, A.; Silva, B.M.; Palmeira-de-Oliveira, R.; Martinez-de-Oliveira, J.; Salgueiro, L. Are plant extracts a potential therapeutic approach for genital infections? Curr. Med. Chem. 2013, 20, 2914-2928. [CrossRef]

18. Vieira, P.D.B.; Giordani, R.B.; Macedo, A.J.; Tasca, T. Natural and synthetic compound anti-Trichomonas vaginalis: An update review. Parasitol. Res. 2015, 114, 1249-1261. [CrossRef]

19. Mallo, N.; Lamas, J.; Leiro, J.M. Hydrogenosome metabolism is the key target for antiparasitic activity of resveratrol against Trichomonas vaginalis. Antimicrob. Agents Chemother. 2013, 57, 2476-2484. [CrossRef]

20. Wachter, B.; Syrowatka, M.; Obwaller, A.; Walochnik, J. In vitro efficacy of curcumin on Trichomonas vaginalis. Wien. Klin. Wochenschr. 2014, 126, S32-S36. [CrossRef]

21. Jurenka, J.S. Anti-inflammatory properties of curcumin, a major constituent of Curcuma longa: A review of preclinical and clinical research. Altern. Med. Rev. 2009, 14, 141-153, Erratum in: Altern. Med. Rev. 2009, 14, 277. [PubMed] 
22. Nagajyothi, F.; Zhao, D.; Weiss, L.M.; Tanowitz, H.B. Curcumin treatment provides protection against Trypanosoma cruzi infection. Parasitol. Res. 2012, 110, 2491-2499. [CrossRef] [PubMed]

23. Tu, C.T.; Yao, Q.Y.; Xu, B.L.; Wang, J.Y.; Zhou, C.H.; Zhang, S.C. Protective effects of curcumin against hepatic fibrosis induced by carbon tetrachloride: Modulation of high-mobility group box 1, Toll-like receptor 4 and 2 expression. Food Chem. Toxicol. 2012, 50, 3343-3351. [CrossRef] [PubMed]

24. Moghadamtousi, S.Z.; Kadir, H.A.; Hassandarvish, P.; Tajik, H.; Abubakar, S.; Zandi, K. A review on antibacterial, antiviral, and antifungal activity of curcumin. BioMed Res. Int. 2014, 2014, 186864. [CrossRef] [PubMed]

25. Rainey, N.E.; Moustapha, A.; Saric, A.; Nicolas, G.; Sureau, F.; Petit, P.X. Iron chelation by curcumin suppresses both curcumin-induced autophagy and cell death together with iron overload neoplastic transformation. Cell Death Discov. 2019, 5, 150. [CrossRef]

26. Gorrell, T.E. Effect of culture medium iron content on the biochemical composition and metabolism of Trichomonas vaginalis. J. Bacteriol. 1985, 161, 1228-1230. [CrossRef]

27. Kim, Y.S.; Song, H.O.; Choi, I.H.; Park, S.J.; Ryu, J.S. Hydrogenosomal activity of Trichomonas vaginalis cultivated under different iron conditions. Korean J. Parasitol. 2006, 44, 373-378. [CrossRef]

28. Aoyagi, S.; Archer, T.K. Differential glucocorticoid receptor-mediated transcription mechanisms. J. Biol. Chem. 2011, 286, 4610-4619. [CrossRef]

29. Chen, W.; Dang, T.; Blind, R.D.; Wang, Z.; Cavasotto, C.N.; Hittelman, A.B.; Rogatsky, I.; Logan, S.K.; Garabedian, M.J. Glucocorticoid receptor phosphorylation differentially affects target gene expression. Mol. Endocrinol. 2008, 22, 1754-1766. [CrossRef]

30. Mobasheri, A.; Henrotin, Y.; Biesalski, H.K.; Shakibaei, M. Scientific evidence and rationale for the development of curcumin and resveratrol as nutraceutricals for joint health. Int. J. Mol. Sci. 2012, 13, 4202-4232. [CrossRef]

31. He, Y.; Yue, Y.; Zheng, X.; Zhang, K.; Chen, S.; Du, Z. Curcumin, inflammation, and chronic diseases: How are they linked? Molecules 2015, 20, 9183-9213. [CrossRef] [PubMed]

32. EFSA. Panel on Food Additives and Nutrient Sources added to Food (ANS), Scientific Opinion on the reevaluation of curcumin (E 100) as a food additive. EFSA J. 2010, 8, 1679-1725. [CrossRef]

33. Smutná, T.; Gonçalves, V.L.; Saraiva, L.M.; Tachezy, J.; Teixeira, M.; Hrdy, I. Flavodiiron protein from Trichomonas vaginalis hydrogenosomes: The terminal oxygen reductase. Eukaryot. Cell 2009, 8, 47-55. [CrossRef] [PubMed]

34. Sommer, U.; Costello, C.E.; Hayes, G.R.; Beach, D.H.; Gilbert, R.O.; Lucas, J.J.; Singh, B.N. Identification of Trichomonas vaginalis cysteine proteases that induce apoptosis in human vaginal epithelial cells. J. Biol. Chem. 2005, 280, 23853-23860. [CrossRef] [PubMed]

35. Neale, K.A.; Alderete, J.F. Analysis of the proteinases of representative Trichomonas vaginalis isolates. Infect. Immun. 1990, 58, 157-162. [CrossRef]

36. Cobo, E.R.; Reed, S.L.; Corbeil, L.B. Effect of vinyl sulfone inhibitors of cysteine proteinases on Tritrichomonas foetus infection. Int. J. Antimicrob. Agents 2012, 39, 259-262. [CrossRef]

37. Hirt, R.P. Trichomonas vaginalis virulence factors: An integrative overview. Sex. Transm. Infect. 2013, 89, 439-443. [CrossRef]

38. Vazeille, E.; Slimani, L.; Claustre, A.; Magne, H.; Labas, R.; Béchet, D.; Taillandier, D.; Dardevet, D.; Astruc, T.; Attaix, D.; et al. Curcumin treatment prevents increased proteasome and apoptosome activities in rat skeletal muscle during reloading and improves subsequent recovery. J. Nutr. Biochem. 2012, 23, 245-251. [CrossRef]

39. Priyanka, A.; Anusree, S.S.; Nisha, V.M.; Raghu, K.G. Curcumin improves hypoxia induced dysfunctions in 3T3-L1 adipocytes by protecting mitochondria and down regulating inflammation. Biofactors 2014, 40, 513-523. [CrossRef]

40. Prasad, S.; Gupta, S.C.; Tyagi, A.K.; Aggarwal, B.B. Curcumin, a component of golden spice: From bedside to bench and back. Biotechnol. Adv. 2014, 32, 1053-1064. [CrossRef]

41. Park, G.C.; Ryu, J.S.; Min, D.Y. The role of nitric oxide as an effector of macrophage-mediated cytotoxicity against Trichomonas vaginalis. Korean J. Parasitol. 1997, 35, 189-195. [CrossRef] [PubMed]

42. Gradoni, L.; Ascenzi, P. Nitric oxide and anti-protozoan chemotherapy. Parassitologia 2004, 46, 101-103. [PubMed] 
43. Trujillo, J.; Granados-Castro, L.F.; Zazueta, C.; Andérica-Romero, A.C.; Chirino, Y.I.; Pedraza-Chaverrí, J. Mitochondria as a target in the therapeutic properties of curcumin. Archiv Pharm. (Weinh.) 2014, 347, 873-884. [CrossRef] [PubMed]

44. Leiro, J.; Arranz, J.A.; Fraiz, N.; Sanmartín, M.L.; Quezada, E.; Orallo, F. Effect of cis-resveratrol on genes involved in nuclear factor kappa B signaling. Int. Immunopharmacol. 2005, 5, 393-406. [CrossRef] [PubMed]

45. Yu, Y.; Shen, Q.; Lai, Y.; Park, S.Y.; Ou, X.; Lin, D.; Jin, M.; Zhang, W. Anti-inflammatory effects of curcumin in microglial cells. Front. Pharmacol. 2018, 9, 386. [CrossRef] [PubMed]

46. Teiten, M.H.; Reuter, S.; Schmucker, S.; Dicato, M.; Diederich, M. Induction of heat shock response by curcumin in human leukemia cells. Cancer Lett. 2009, 279, 145-154. [CrossRef] [PubMed]

47. Knowlton, A.A. NFkappaB, heat shock proteins, HSF-1, and inflammation. Cardiovasc. Res. 2006, 6, 7-8. [CrossRef]

48. Shen, S.Q.; Zhang, Y.; Xiang, J.J.; Xiong, C.L. Protective effect of curcumin against liver warm ischemia/reperfusion injury in rat model is associated with regulation of heat shock protein and antioxidant enzymes. World J. Gastroenterol. 2007, 13, 1953-1961. [CrossRef]

49. Khan, S.; Heikkila, J.J. Curcumin-induced inhibition of proteasomal activity, enhanced HSP accumulation and the acquisition of thermotolerance in Xenopus laevis A6 cells. Comp. Biochem. Physiol. A Mol. Integr. Physiol. 2011, 158, 566-576. [CrossRef]

50. Xia, C.; Cai, Y.; Li, S.; Yang, J.; Xiao, G. Curcumin increases HSP70 expression in primary rat cortical neuronal apoptosis induced by gp120 V3 loop peptide. Neurochem. Res. 2015, 40, 1996-2005. [CrossRef]

51. Diamond, L.S. The establishment of various trichomonads of animals and man in axenic cultures. J. Parasitol. 1957, 43, 488-490. [CrossRef] [PubMed]

52. León-Rodríguez, L.; Luzardo-Álvarez, A.; Blanco-Méndez, J.; Lamas, J.; Leiro, J. Biodegradable microparticles covalently linked to surface antigens of the scuticociliate parasite $P$. dicentrarchi promote innate immune responses in vitro. Fish Shellfish Immunol. 2013, 34, 236-243. [CrossRef] [PubMed]

53. Paramá, A.; Iglesias, R.; Álvarez, M.F.; Leiro, J.; Ubeira, F.M.; Sanmartín, M.L. Cysteine proteinase activities in the fish pathogen Philasterides dicentrarchi (Ciliophora: Scuticociliatida). Parasitology 2004, 128, 541-548. [CrossRef] [PubMed]

54. Bradford, M. A rapid and sensitive method for the quantitation of microgram quantities of protein utilizing the principle of protein dye binding. Anal. Biochem. 1976, 72, 248-254. [CrossRef]

55. Piazzon, C.; Lamas, J.; Leiro, J.M. Role of scuticociliate proteinases in infection success in turbot, Psetta maxima (L.). Parasite Immunol. 2011, 33, 535-544. [CrossRef]

56. Griess, P. Bemerkungen zu der abhandlung der HH. Weselsky und Benedikt "Ueber einige azoverbindungen". Chem. Ber. 1879, 12, 426-428. [CrossRef]

57. Leiro, J.M.; Castro, R.; Arranz, J.A.; Lamas, J. Immunomodulating activities of acidic sulphated polysaccharides obtained from the seaweed Ulva rigida C. Agardh. Int. Immunopharmacol. 2007, 7, 879-888. [CrossRef]

58. Livak, K.J.; Schmittgen, T.D. Analysis of relative gene expression data using real-time quantitative PCR and the 2- Delta Delta Ct method. Methods 2001, 25, 402-408. [CrossRef]

59. Bustin, S.A.; Benes, V.; Garson, J.A.; Hellemans, J.; Huggett, J.; Kubista, M.; Mueller, R.; Nolan, T.; Pfaffl, M.W.; Shipley, G.L.; et al. The MIQE guidelines: Minimum information for publication of quantitative real-time PCR experiments. Clin. Chem. 2009, 55, 611-622. [CrossRef]

60. Piazzon, C.; Lamas, J.; Castro, R.; Budiño, B.; Cabaleiro, S.; Sanmartín, M.L.; Leiro, J. Antigenic and cross-protection studies on two turbot scuticociliate isolates. Fish Shellfish Immunol. 2008, 25, 417-424. [CrossRef]

Sample Availability: Samples of the compounds curcumin are available from the authors.

Publisher's Note: MDPI stays neutral with regard to jurisdictional claims in published maps and institutional affiliations.

(C) 2020 by the authors. Licensee MDPI, Basel, Switzerland. This article is an open access article distributed under the terms and conditions of the Creative Commons Attribution (CC BY) license (http://creativecommons.org/licenses/by/4.0/). 